\title{
Perbandingan Kurva S-N dalam Menentukan Umur Kelelahan Struktur
}

\author{
Arianta $^{1 *}$, Frengki H. Pardede ${ }^{2}$ dan Fransisko ${ }^{1}$ \\ Dikirim: 06/09/2021 \\ Diterima: $17 / 09 / 2021$
}

\begin{abstract}
ABSTRAK
Struktur anjungan lepas pantai merupakan infrastruktur yang menyokong proses pengeboran minyak di lepas pantai. Sebagian besar struktur anjungan lepas pantai di Indonesia berdiri sejak tahun 1971. Faktor utama masih beroperasi anjungan lepas pantai adalah terkait dengan kebutuhan masyarakat akan minyak bumi. Oleh karena itu, perlu menjadi perhatian khusus agar struktur anjungan lepas pantai dapat beroperasi dengan aman. Analisis kelelahan (fatigue) struktur akan memberika estimasi umur kelelahan struktur, yang mana dapat dijadikan acuan dalam melakukan pencegahan terhadap kegagalan struktur. American Petroleum Institute (API) mengeluarkan dua jenis kurva S-N dalam penentuan umur kelelahan struktur yaitu API X-X' dan WJT (Welded Joint). Kurva S-N WJT merupakan kruva S-N baru yang dikeluarkan oleh API pada tahun 2014. Dengan adanya kurva S-N terbaru, untuk struktur anjungan lepas pantai tua (sejak tahun 1973) yang masih beroperasi sampai saat ini diperlukan penyesuaian dalam menentukan umur kelelahan. Penelitian ini akan membandingkan analisis kelelahan menggunakan kedua grafik tersebut. Berdasarkan hasil penelitian diperoleh kurva S-N WJ menghasilkan umur kelelahan yang lebih kecil dibandingkan dengan kurva S-N API X. Secara persentase rentang perbedaan hasilnya adalah $11 \%-79 \%$, hal ini bergantung pada lokasi dan elevasi komponen struktur.
\end{abstract}

Kata kunci: fatigue, kurva S-N, struktur anjungan lepas pantai, umur kelelahan

\section{PENDAHULUAN}

Struktur anjungan lepas pantai sebagai pendukung teknologi ekploitasi minyak dan gas bumi sudah berdiri di Indonesia sejak tahun 1971 dan tipe anjungan lepas pantai yang digunakan adalah fixed jacket platform [1]. Berdasakan data SKK Migas tahun 2016 [2], sebanyak 613 anjungan lepas pantai yang terpasang dan tersebar di Laut Jawa, Selat Madura dan Selat Makasar. Diketahui bahwa terdapat 55\% atau 335 unit anjungan lepas pantai yang mempunyai umur lebih dari 20 tahun dan masih dapat beroperasi. Gambar 1 menunjukkan data umur struktur anjungan lepas pantai yang masih beroperasi.

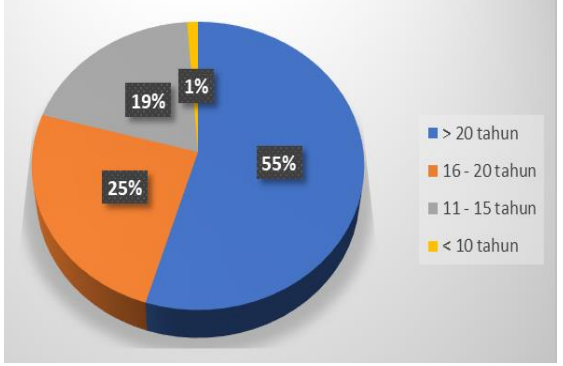

Gambar 1. Data Umur Struktur Anjungan Lepas Pantai yang Beroperasi [2]

\footnotetext{
${ }^{1}$ Universitas Pertamina, Jl. Teuku Nyak Arief, Jakarta 12220

2 PT. Singgar Mulia, Jl. Pakubuwono VI No.31, Jakarta Selatan 12120

*arianta1@universitaspertamina.ac.id
} 
Struktur anjungan lepas pantai pada umumnya didesain selama 20 tahun atau sesuai dengan target produksi [3]. Namun pada kenyataannya struktur anjungan lepas pantai masih kuat beroperasi melebihi dari 20 tahun. Pada saat pengoperasiannya sering sekali terjadi penambahan modul untuk menambah produksi minyak atau gas bumi. Sebelum dilakukan penambahan modul, perlu dilakukan penilaian ulang kekuatan struktur. Apakah struktur masih kuat dan aman menahan beban tambahan atau diperlukan suatu modifikasi.

Salah satu analisis yang perlu dilakukan untuk menilai kekuatan strutkur adalah analisa kelelahan (fatigue). Analisa ini menggunakan kurva hubungan antara tegangan (stress) dengan siklus (cycle), kurva S-N, yang kemudian dapat ditentukan umur kelelahan dari struktur. Standar API RP 2A merupakan acuan dasar dalam melakukan desain struktur anjungan lepas pantai. Pada tahun 2014 API RP 2A mengeluarkan kurva S-N baru yang dinamakan kurva S-N WJT (Welded Joints), sebelumnya adalah kurva S-N X-X' [4]. Dengan keluarnya kurva S-N WJT menjadikan ada perbedaan evaluasi terhadap umur kelelahan terutama untuk struktur anjungan lepas pantai yang sudah terpasang sejak tahun 1970 an. Hal ini terjadi pada saat melakukan penilaian kekuatan struktur apabila anjungan lepas pantai lama (berdiri sejak tahun 1970 an) masih beroperasi sampai melewati tahun 2014. Gambar 2 berikut menunjukkan batasan penggunaan kurva S-N, sehingga diperlukan evaluasi kekuatan struktur dengan dua kurva S-N.

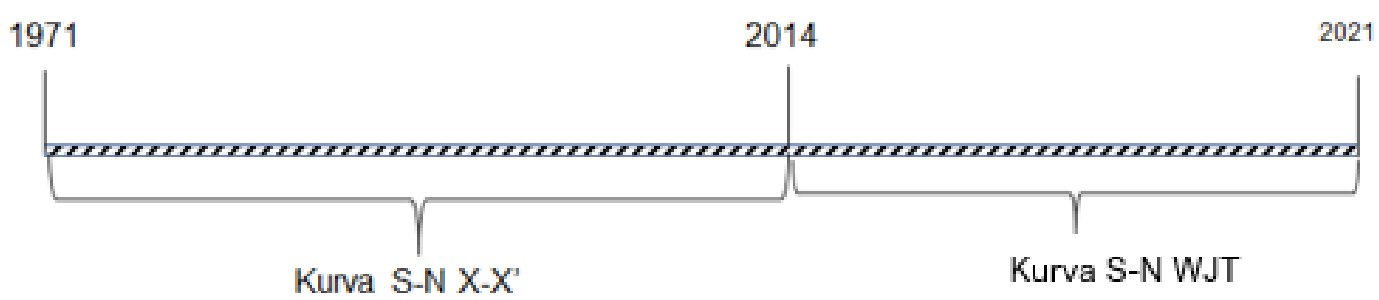

Gambar 2. Batasan Penggunaan Kurva S-N

\section{TINJAUAN PUSTAKA}

Analisis kelelahan atau fatigue merupakan elemen penting dalam desain dan penilaian kekuatan struktur anjungan lepas pantai. Keluaran dari analisis kelelahan ini adalah estimasi umur layan atau umur kelelahan dari struktur. Faktor yang mempengaruhi penentuan umur kelelahan adalah beban yang berulang atau siklik. Pada kasus struktur anjungan lepas pantai beban sklik yang berlaku adalah gaya gelombang laut. Bentuk ideal gelombang laut mengikuti bentuk sinusoidal, yang mana memiliki puncak dan lembah gelombang dalam satu perioda. Gambar 3 memperlihatkan betuk ideal gaya gelombang laut.

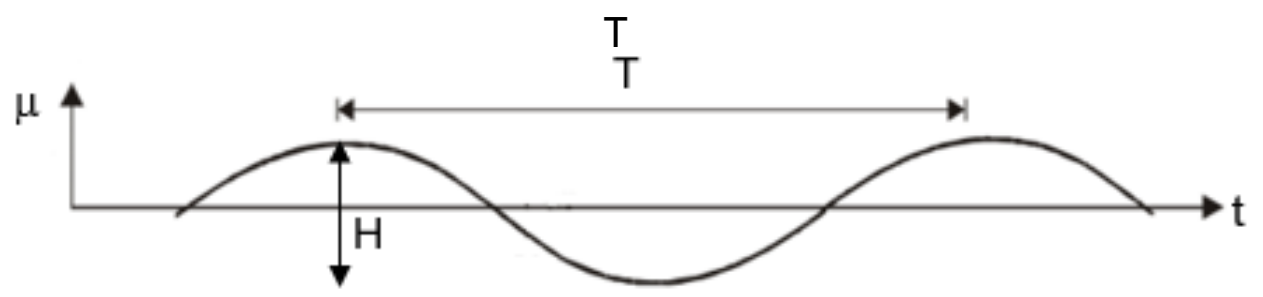

Gambar 3. Gelombang Laut [4]

Dimana $\mathrm{H}$ adalah tinggi gelombang laut, $\mathrm{T}$ adalah perioda gelombang laut, $\mathrm{t}$ adalah waktu, dan $\mu$ adalah elevasi muka air. Gelombang laut akan memberikan repon struktur yang berbedabeda dalam kurun waktur tertentu. Sehingga struktur akan menghasilkan nilai tegangan yang bervariasi. Dalam penentuan umur kelelahan dari nilai tegangan yang bervariasi diperlukan suatu kurva hubungan tegangan dengan siklus, yang disebut dengan kurva S-N. Pada berbagai penenlitian terdahulu penggunaan kurva S-N mengacu pada standar yang sering digunakan dalam desain struktur anjungan lepas pantai. Paulo et al [5] dan Antonio [6] menggunakan kurva 
S-N dari standar DNV [7] untuk menentukan umur kelelahan. Rohith dan Jayalekshmi [8] melakukan analisis kelelahan menggunakan kurva S-N dari standar API-WJT [3], dengan membuat perbandingan antara metode analisis gelombang laut deterministik dan spektral. Dalam penelitian lainnya, Khalifa et al [9] melakukan penilaian kelelahan pada struktur anjungan lepas pantai di daerah Egypt menggunakan kurva S-N dari standar API-X' [10]. Kurva S-N sebagai penentuan umur kelelahan dapat diambil dari berbagai standar yang sesuai dengan posisi lokasi yang diteliti. Struktur anjungan lepas pantai di Indonesia mengacu kepada standar API untuk melakukan desain dan penilaian kekuatan strukturnya. Standar API edisi terakhir telah mengeluarkan kurva S-N baru (WJT) [3], yang cukup berbeda dengan kurva S-N lama (X-X'). Pada penelitian ini dilakukan kajian perbandingan kurva S-N dari standari API yaitu kurva S-N XX' dengan kurva S-N WJT.

Kurva S-N X-X' merupakan kurva S-N pertama yang digunakan untuk menentukan umur kelelahan berdasarkan standar API [10]. Kurva ini berlaku untuk beban acak dan menganggap bahwa proteksi katodik untuk mencegah korosi bekerja dengan efektif. Untuk zona basah-kering (splash zone) diasumsikan terbebas dari korosi atau tidak mempertimbangkan kondisi korosi yang berlebihan, dan disarankan tidak ada sambungan antar komponen struktur. Kurva S-N X-X' terdiri dari Kurva X' dan X. Kurva S-N X' digunakan pada kasus pengelasan tanpa kontrol profil, namun memenuhi dengan standar AWS D.1.1 [11] dan memiliki ketebalan komponen struktur kurang dari 0,625 inci $(16 \mathrm{~mm})$. Sedangkan kurva S-N X berlaku untuk kondisi pengelasan dengan kontrol profil dan memiliki ketebalan komponen struktur kurang dari 1 inci $(25 \mathrm{~mm})$ dan lebih besar dari $16 \mathrm{~mm}$. Persamaan 2 merupakan pembentuk kurva S-N X-X'

$$
N=2 \times 10^{6}\left(\frac{\Delta_{\sigma}}{\Delta_{\text {oref }}}\right)^{-m}
$$

dimana nilai $\mathrm{N}$ adalah prediksi jumlah siklus kegagalan komponen struktur dalam rentang tegangan $\left(\Delta_{\sigma}\right), \Delta_{\sigma r e f}$ adalah rentang tegangan referensi sesuai kurva $\mathrm{S}-\mathrm{N}$ yang digunakan, dan $\mathrm{m}$ adalah kemiringangn kurva. Tabel 1 merupakan nilai parameter $\Delta_{\text {rref, }}$ dan $\mathrm{m}$ ditentukan sesuai dengan tipe kurva yang akan digunakan. Kurva S-N X-X' ditunjukkan pada gambar 4.

Tabel 1. Nilai parameter kurva S-N X-X'

\begin{tabular}{cccc}
\hline Kurva & $\Delta_{\text {rref }}$ & $\mathbf{m}$ & Batas Tahanan pada siklus 200 juta \\
\hline $\mathrm{X}$ & $14,5 \mathrm{ksi}(100 \mathrm{MPa})$ & 4,38 & $5,07 \mathrm{ksi}(35 \mathrm{MPa})$ \\
$\mathrm{X}^{\prime}$ & $11,4 \mathrm{ksi}(79 \mathrm{MPa})$ & 3,74 & $3,33 \mathrm{ksi}(23 \mathrm{MPa})$ \\
\hline
\end{tabular}

Kurva S-N WJT merupakan kurva S-N terbaru yang dikeluarkan oleh API pada tahun 2014. Pada kurva S-N ini sudah mempertimbangkan faktor korosi pada zona basah-kering dan komponen struktur yang menggunakan proteksi katodik di area bawah air. Hal ini dapat dilihat pada gambar 5, yang mana terdapat dua kurva S-N yang disesuaikan dengan lokasi komponen struktur yang ditinjau. Untuk kurva S-N Air berlaku untuk komponen struktur pada area basahkering dan area kering. Sedangkan kurva S-N cathodic protection untuk komponen struktur yang menggunakan proteksi katodik sebagai pencegahan korosi. Pada area basah-kering diperbolehkan adanya sambungan antar komponen struktur. Desain kurva S-N WJT dapat diperoleh dengan persamaan 3 berikut. 


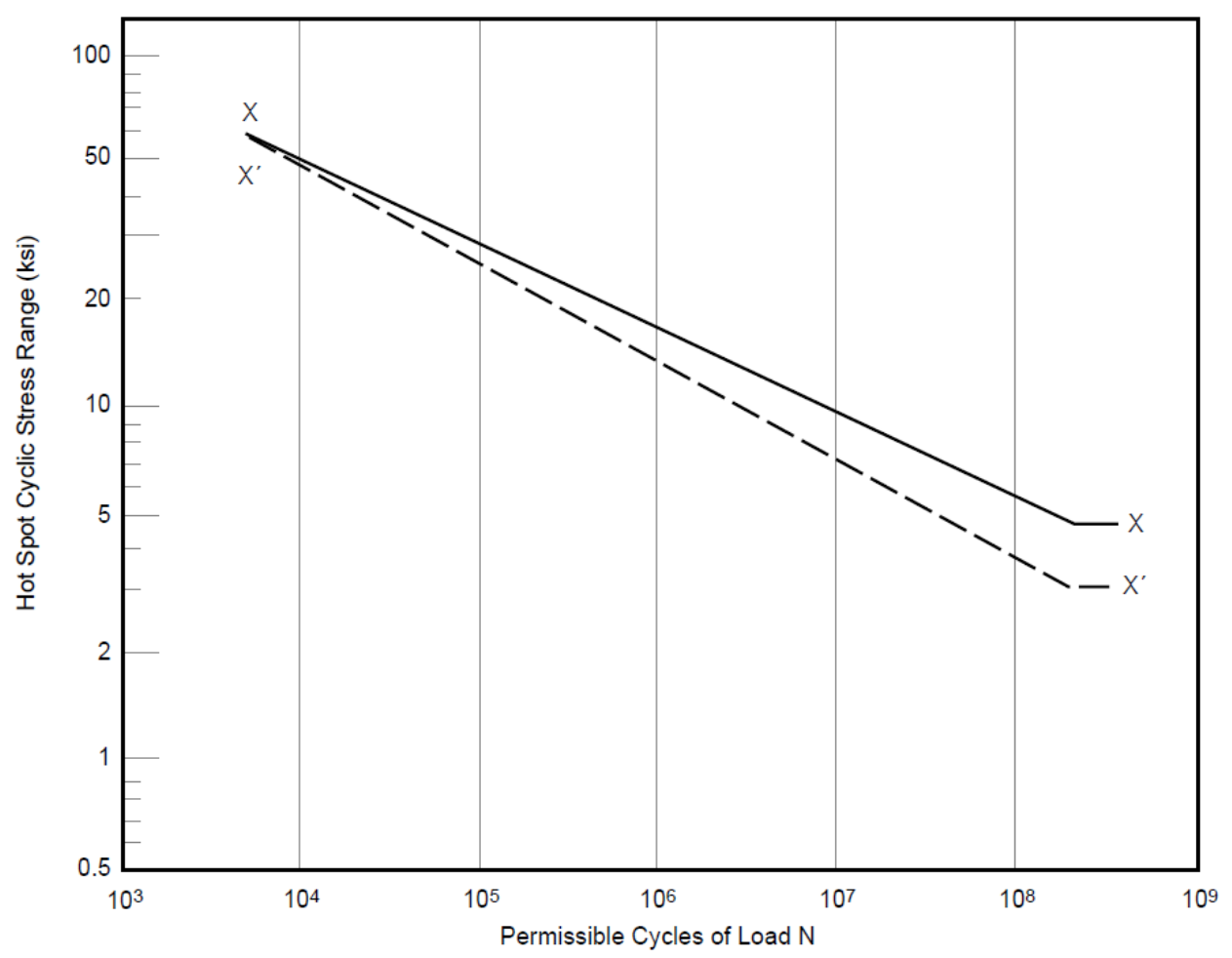

Gambar 4. Kurva S-N X-X' [10]

$$
\log _{10}(N)=\log _{10}\left(k_{1}\right)-m \log _{10}(S)
$$

dimana $\mathrm{N}$ adalah estimasi angka siklus kegagalan struktur dari rentang tegangan (S), dan k1 adalah suatu konstanta. Nilai parameter $\log 10(\mathrm{k} 1)$ dan $\mathrm{m}$ disajikan pada tabel 2 berikut ini.

Tabel 2. Nilai Parameter Kurva S-N WJT

\begin{tabular}{ccc}
\hline Kurva & $\begin{array}{c}\log _{10}\left(\mathbf{k}_{\mathbf{1}}\right) \\
(\mathbf{M P a})\end{array}$ & $\mathbf{m}$ \\
\hline \multirow{2}{*}{ WJT } & 12,48 & 3 untuk $\mathrm{N}<10^{7}$ \\
& 16,13 & 5 untuk $\mathrm{N}>0^{7}$ \\
\hline
\end{tabular}

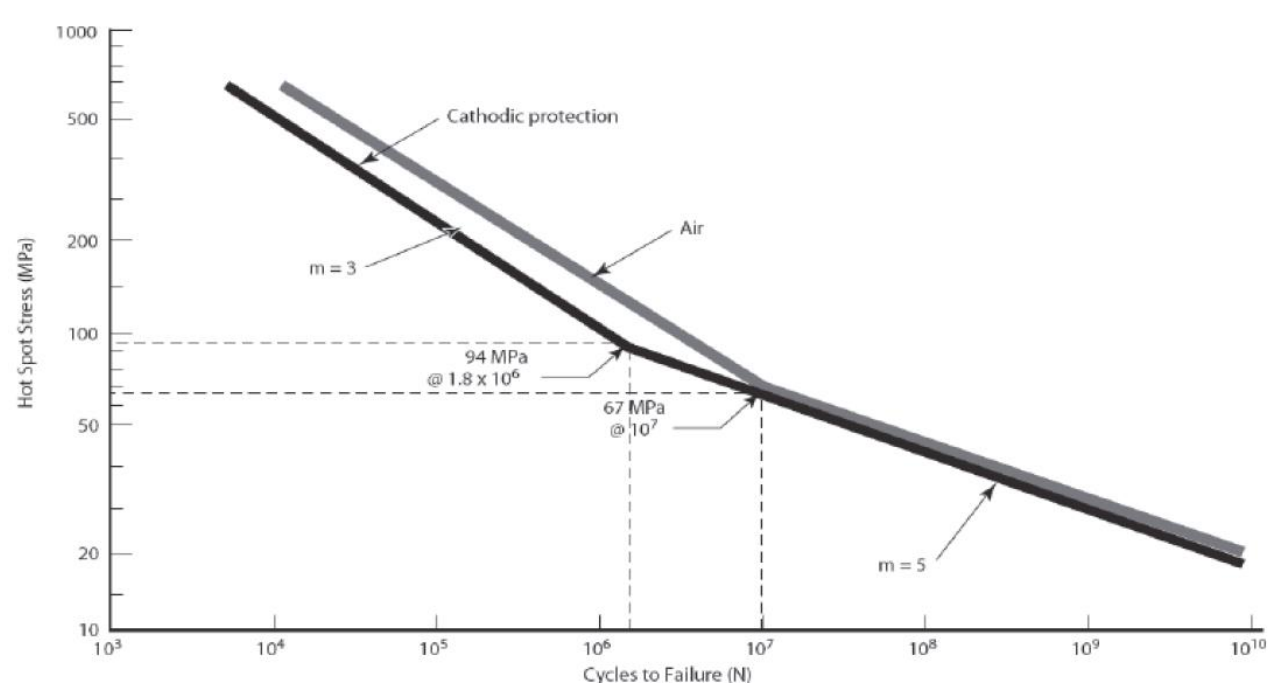

Gambar 5. Kurva S-N WJT [3] 
Respon komponen struktur dari gaya gelombang laut menghasilkan variasi nilai tegangan yang terjadi. Dengan menggunakan kurva S-N, ditentukan nilai siklus kegagalan $(\mathrm{N})$ dari variasi nilai tegangan. Kemudian nilai siklus kegagalan digunakan untuk menentukan nilai total kerusakan pada persamaan 3 .

$$
D=\sum_{i=1}^{m} \frac{n_{i}}{N_{i}}=\frac{n_{1}}{N_{1}}+\frac{n_{2}}{N_{2}}+\frac{n_{3}}{N_{3}}+\ldots+\frac{n_{m}}{N_{m}}
$$

dengan $n_{i}=$ jumlah siklus yang terjadi pada rentang tegangan tertentu, dan $\mathrm{N}_{\mathrm{i}}=$ jumlah siklus pada rentangan tegangan yang dihasilkan dari kurva S-N.

\section{METODOLOGI PENELITIAN}

Struktur anjungan lepas pantai pada kasus ini berdiri pada tahun 1973 dan dilakukan penambahan masa layan sampai dengan tahun 2022. Oleh karena itu, dalam penentuan umur kelelahan digunakan dua kurva S-N sesuai dengan gambar 2. Struktur anjungan lepas pantai yang ditinjau mempunyai 3 kaki, 3 pipa konduktor dan terpasang pada kedalaman $32 \mathrm{~m}$ di bawah permukaan laut. Terdapat 2 tingkatan deck yaitu lower deck pada elevasi $+10,80 \mathrm{~m}$ dan upper deck pada elevasi $+16,25 \mathrm{~m}$, diperlihatkan pada gambar 6 . Selama masa operasi, struktur anjungan lepas pantai ini menerima beban berulang yang bersumber dari gelombang laut, arus laut dan angin. Untuk analisis kelelahan beban berulang yang digunakan adalah gelombang laut dari 16 arah mata angin, gambar 7.

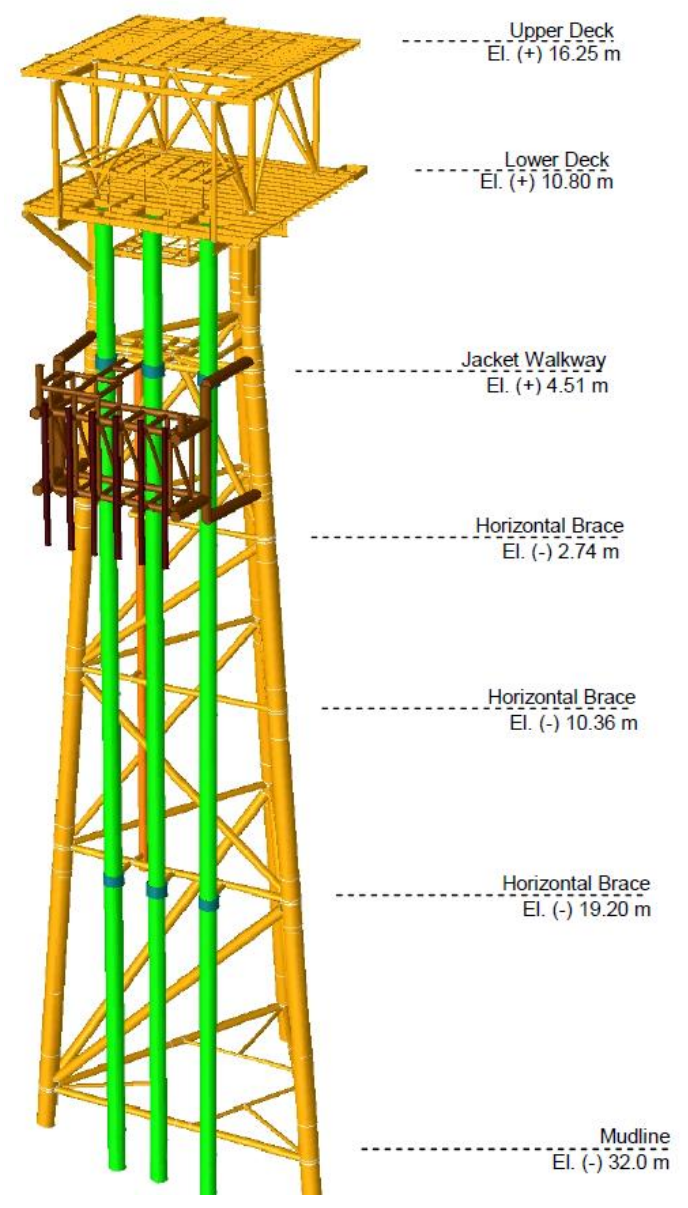

Gambar 6. Model struktur anjungan lepas pantai 3 kaki 


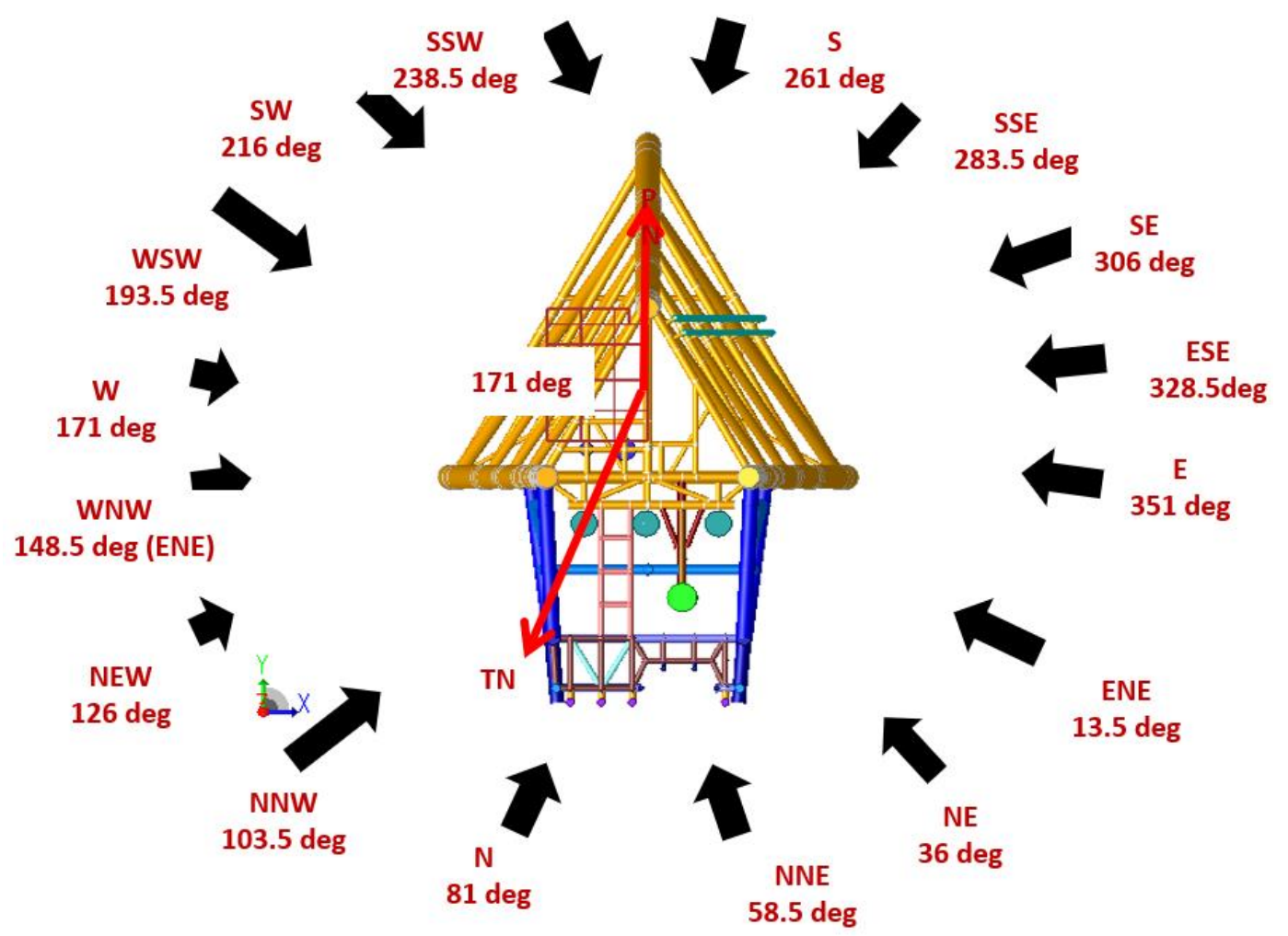

Gambar 7. Tinjauan 16 arah gelombang laut

Metode analisis kelelahan yang digunakan adalah metode spektral. Metode spektral menggunakan pendekatan statistik untuk menghitung total kerusakan yang terjadi pada struktur. Pendekatan yang dilakukan dengan memanfaatkan spektrum gelombang laut dan fungsi transfer, sehingga akan didapatkan repson struktur dari tinggi gelombang laut tertentu [8]. Hal yang terpenting dalam metode ini ialah penentuan fungsi transfer rentang tegangan, yang menjelaskan hubungan antara besar tegangan pada lokasi struktur tertentu yang berhubungan dengan ketinggian, frekuensi dan besar sudut gelombang laut. Pada penelitian ini meninjau tiga skenario analisis kelelahan sebagai berikut.

1. Skenario pertama yaitu menghitung total kerusakan menggunakan kurva S-N X dari tahun 1973 sampai dengan tahun 2022.

2. Skenario kedua yaitu menghitung total kerusakan kerusakan menggunakan dua kurva S-N, yakni kurva S-N X untuk menghitung total damage struktur dari tahun 1973 hingga 2014 dan penggunaan kurva S-N WJ dari tahun 2014 hingga 2022.

3. Skenario ketiga yaitu menggunakan total kerusakan menggunakan kurva S-N WJ untuk menghitung total kerusakan struktur mulai dari tahun 1973 hingga 2022.

\section{HASIL DAN PEMBAHASAN}

Analisis kelelahan dilakukan dengan menggunakan alat bantu perangkat lunak SACS untuk mendapatkan nilai total kerusakan dan umur kelalahan struktur. Perhitungan umur kelelahan pada sambungan, terhitung mulai dari tahun instalasi anjungan lepas pantai yakni pada tahun 1973. Apabila nilai perhitungan umur kelelahan $\left(t_{\text {fat }}\right)$ melebihi nilai minimum umur kelelahan $\left(t_{\text {req }}\right)$, maka sambungan tersebut memenuhi umur desain operasional (passed) atau dengan kata lain sambungan tersebut dapat menahan beban dinamis selama masa operasionalnya. Sebaliknya apabila nilai $t_{\text {fat }}$ dibawah nilai $t_{\text {req, }}$ maka sambungan tidak memenuhi umur rencana (not passed). Tabel 3 sampai tabel 5 memperlihatkan hasil analisis kelelahan pada setiap sambungan utama berdasarkan skenario yang dilakukan. 
Tabel 3. Skenario 1 menggunakan kurva S-N X

\begin{tabular}{cccccccc}
\hline No & $\begin{array}{c}\text { Elevasi } \\
(\mathbf{m})\end{array}$ & $\begin{array}{c}\text { Nomer } \\
\text { Sambungan }\end{array}$ & $\begin{array}{c}\text { Tipe } \\
\text { Sambungan }\end{array}$ & $\begin{array}{c}\text { Total } \\
\text { Kerusakan }\end{array}$ & $\begin{array}{c}\mathbf{t}_{\text {fat }} \\
(\text { tahun) }\end{array}$ & $\begin{array}{c}\mathbf{t}_{\text {req }} \\
\text { (tahun) }\end{array}$ & Keterangan \\
\hline 1 & 4,51 & 5000 & $\mathrm{~K}$ & 16,107 & 3,04 & 98 & tidak memenuhi \\
2 & 4,51 & 5013 & $\mathrm{~K}$ & 1,141 & 42,93 & 98 & tidak memenuhi \\
3 & 4,51 & 5014 & $\mathrm{~K}$ & 0,450 & 108,90 & 98 & memenuhi \\
4 & 4,51 & 5015 & $\mathrm{~T}$ & 0,623 & 78,71 & 98 & tidak memenuhi \\
5 & 4,51 & $501 \mathrm{~L}$ & $\mathrm{~T}$ & 0,006 & 7696,54 & 98 & memenuhi \\
6 & 4,51 & $502 \mathrm{~L}$ & $\mathrm{~T}$ & 0,014 & 3484,79 & 98 & memenuhi \\
7 & 4,51 & $503 \mathrm{~L}$ & $\mathrm{~K}$ & 0,065 & 752,54 & 98 & memenuhi \\
8 & $-2,74$ & $401 \mathrm{~L}$ & $\mathrm{~K}$ & 1,038 & 47,21 & 98 & tidak memenuhi \\
9 & $-2,74$ & $402 \mathrm{~L}$ & $\mathrm{TK}$ & 0,249 & 197,05 & 98 & memenuhi \\
10 & $-2,74$ & $403 \mathrm{~L}$ & $\mathrm{~K}$ & 0,111 & 443,01 & 98 & memenuhi \\
11 & $-10,36$ & $301 \mathrm{~L}$ & $\mathrm{TK}$ & 0,083 & 593,03 & 98 & memenuhi \\
12 & $-10,36$ & $302 \mathrm{~L}$ & $\mathrm{~K}$ & 0,076 & 644,69 & 98 & memenuhi \\
13 & $-10,36$ & $303 \mathrm{~L}$ & $\mathrm{~K}$ & 0,077 & 637,96 & 98 & memenuhi \\
14 & $-19,2$ & $201 \mathrm{~L}$ & $\mathrm{~T}$ & 0,719 & 68,17 & 98 & tidak memenuhi \\
15 & $-19,2$ & $202 \mathrm{~L}$ & $\mathrm{TK}$ & 1,110 & 44,16 & 98 & tidak memenuhi \\
16 & $-19,2$ & $203 \mathrm{~L}$ & $\mathrm{~K}$ & 0,073 & 667,61 & 98 & memenuhi \\
17 & $-30,5$ & $101 \mathrm{~L}$ & $\mathrm{~K}$ & 0,029 & 1710,31 & 98 & memenuhi \\
18 & $-30,5$ & $102 \mathrm{~L}$ & $\mathrm{~T}$ & 0,163 & 300,06 & 98 & memenuhi \\
19 & $-30,5$ & $103 \mathrm{~L}$ & $\mathrm{Y}$ & 0,002 & 22710,00 & 98 & memenuhi \\
\hline
\end{tabular}

Tabel 4. Skenario 2 menggunakan kurva S-N X dan kurva S-N WJT

\begin{tabular}{cccccccc}
\hline No & $\begin{array}{c}\text { Elevasi } \\
(\mathbf{m})\end{array}$ & $\begin{array}{c}\text { Nomer } \\
\text { Sambungan }\end{array}$ & $\begin{array}{c}\text { Tipe } \\
\text { Sambungan }\end{array}$ & $\begin{array}{c}\text { Total } \\
\text { Kerusakan }\end{array}$ & $\begin{array}{c}\mathbf{t}_{\text {fat }} \\
\text { (tahun) }\end{array}$ & $\begin{array}{c}\mathbf{t}_{\text {req }} \\
\text { (tahun) }\end{array}$ & Keterangan \\
\hline 1 & 4,51 & 5000 & $\mathrm{~K}$ & 10,757 & 4,56 & 98 & tidak memenuhi \\
2 & 4,51 & 5013 & $\mathrm{~K}$ & 0,894 & 54,79 & 98 & tidak memenuhi \\
3 & 4,51 & 5014 & $\mathrm{~K}$ & 0,367 & 133,49 & 98 & memenuhi \\
4 & 4,51 & 5015 & $\mathrm{~T}$ & 0,508 & 96,53 & 98 & tidak memenuhi \\
5 & 4,51 & $501 \mathrm{~L}$ & $\mathrm{~T}$ & 0,008 & 6317,36 & 98 & memenuhi \\
6 & 4,51 & $502 \mathrm{~L}$ & $\mathrm{~T}$ & 0,015 & 3326,07 & 98 & memenuhi \\
7 & 4,51 & $503 \mathrm{~L}$ & $\mathrm{~K}$ & 0,055 & 887,24 & 98 & memenuhi \\
8 & $-2,74$ & $401 \mathrm{~L}$ & $\mathrm{~K}$ & 0,822 & 59,61 & 98 & tidak memenuhi \\
9 & $-2,74$ & $402 \mathrm{~L}$ & $\mathrm{TK}$ & 0,203 & 241,50 & 98 & memenuhi \\
10 & $-2,74$ & $403 \mathrm{~L}$ & $\mathrm{~K}$ & 0,099 & 494,48 & 98 & memenuhi \\
11 & $-10,36$ & $301 \mathrm{~L}$ & $\mathrm{TK}$ & 0,087 & 562,47 & 98 & memenuhi \\
12 & $-10,36$ & $302 \mathrm{~L}$ & $\mathrm{~K}$ & 0,071 & 687,63 & 98 & memenuhi \\
13 & $-10,36$ & $303 \mathrm{~L}$ & $\mathrm{~K}$ & 0,073 & 672,34 & 98 & memenuhi \\
14 & $-19,2$ & $201 \mathrm{~L}$ & $\mathrm{~T}$ & 0,631 & 77,66 & 98 & tidak memenuhi \\
15 & $-19,2$ & $202 \mathrm{~L}$ & TK & 0,985 & 49,74 & 98 & tidak memenuhi \\
16 & $-19,2$ & $203 \mathrm{~L}$ & $\mathrm{~K}$ & 0,072 & 684,96 & 98 & memenuhi \\
17 & $-30,5$ & $101 \mathrm{~L}$ & $\mathrm{~K}$ & 0,034 & 1452,22 & 98 & memenuhi \\
18 & $-30,5$ & $102 \mathrm{~L}$ & $\mathrm{~T}$ & 0,140 & 349,64 & 98 & memenuhi \\
19 & $-30,5$ & 103L & $\mathrm{Y}$ & 0,003 & 16298,56 & 98 & memenuhi \\
\hline
\end{tabular}


Tabel 5. Skenario 3 menggunakan kurva S-N WJT

\begin{tabular}{cccccccc}
\hline No & $\begin{array}{c}\text { Elevasi } \\
(\mathbf{m})\end{array}$ & $\begin{array}{c}\text { Nomer } \\
\text { Sambungan }\end{array}$ & $\begin{array}{c}\text { Tipe } \\
\text { Sambungan }\end{array}$ & $\begin{array}{c}\text { Total } \\
\text { Kerusakan }\end{array}$ & $\begin{array}{c}\mathbf{t}_{\text {fat }} \\
\text { (tahun) }\end{array}$ & $\begin{array}{c}\mathbf{t}_{\text {req }} \\
\text { (tahun) }\end{array}$ & Keterangan \\
\hline 1 & 4,51 & 5000 & $\mathrm{~K}$ & 10,822 & 4,528 & 98 & tidak memenuhi \\
2 & 4,51 & 5013 & $\mathrm{~K}$ & 1,282 & 38,231 & 98 & tidak memenuhi \\
3 & 4,51 & 5014 & $\mathrm{~K}$ & 0,622 & 78,740 & 98 & tidak memenuhi \\
4 & 4,51 & 5015 & $\mathrm{~T}$ & 0,810 & 60,530 & 98 & tidak memenuhi \\
5 & 4,51 & $501 \mathrm{~L}$ & $\mathrm{~T}$ & 0,029 & 1666,956 & 98 & memenuhi \\
6 & 4,51 & $502 \mathrm{~L}$ & $\mathrm{~T}$ & 0,044 & 1109,994 & 98 & memenuhi \\
7 & 4,51 & $503 \mathrm{~L}$ & $\mathrm{~K}$ & 0,147 & 334,204 & 98 & memenuhi \\
8 & $-2,74$ & $401 \mathrm{~L}$ & $\mathrm{~K}$ & 1,366 & 35,872 & 98 & tidak memenuhi \\
9 & $-2,74$ & $402 \mathrm{~L}$ & $\mathrm{TK}$ & 0,343 & 142,956 & 98 & memenuhi \\
10 & $-2,74$ & $403 \mathrm{~L}$ & $\mathrm{~K}$ & 0,198 & 247,020 & 98 & memenuhi \\
11 & $-10,36$ & $301 \mathrm{~L}$ & $\mathrm{TK}$ & 0,226 & 217,263 & 98 & memenuhi \\
12 & $-10,36$ & $302 \mathrm{~L}$ & $\mathrm{~K}$ & 0,153 & 321,052 & 98 & memenuhi \\
13 & $-10,36$ & $303 \mathrm{~L}$ & $\mathrm{~K}$ & 0,153 & 319,627 & 98 & memenuhi \\
14 & $-19,2$ & $201 \mathrm{~L}$ & $\mathrm{~T}$ & 0,962 & 50,943 & 98 & tidak memenuhi \\
15 & $-19,2$ & $202 \mathrm{~L}$ & $\mathrm{TK}$ & 1,438 & 34,072 & 98 & tidak memenuhi \\
16 & $-19,2$ & $203 \mathrm{~L}$ & $\mathrm{~K}$ & 0,151 & 324,097 & 98 & memenuhi \\
17 & $-30,5$ & $101 \mathrm{~L}$ & $\mathrm{~K}$ & 0,097 & 506,218 & 98 & memenuhi \\
18 & $-30,5$ & $102 \mathrm{~L}$ & $\mathrm{~T}$ & 0,237 & 206,476 & 98 & memenuhi \\
19 & $-30,5$ & $103 \mathrm{~L}$ & $\mathrm{Y}$ & 0,010 & 4780,908 & 98 & memenuhi \\
\hline
\end{tabular}

Dari hasil analisis kelelahan terhadap 19 sambungan utama terdapat beberapa joint utama yang tidak memenuhi nilai umum minimum kelelahan $\left(t_{\text {req }}\right)$. Jumlah sambungan yang memenuhi dan tidak memenuhi pada masing-masing skenario dapat dilihat pada tabel 6 .

Tabel 6. Jumlah sambungan yang memenuhi dan tidak memenuhi

\begin{tabular}{ccccc}
\hline Skenario & $\begin{array}{c}\text { Total } \\
\text { Sambungan }\end{array}$ & $\begin{array}{c}\text { Total } \\
\text { Memenuhi }\end{array}$ & $\begin{array}{c}\text { Total Tidak } \\
\text { Memenuhi }\end{array}$ & $\begin{array}{c}\text { Persentase tidak } \\
\text { memenuhi }\end{array}$ \\
\hline 1 (Kurva S-N X') & 19 & 13 & 6 & $32 \%$ \\
2 (Kurva S-N X' dan WJT) & 19 & 13 & 6 & $32 \%$ \\
3 (Kurva WJT) & 19 & 12 & 7 & $37 \%$ \\
\hline
\end{tabular}

Dari tabel 6 terlihat nilai persentase tidak memenuhi untuk skenario 1 dan 2 memiliki persentase yang sama yaitu $36 \%$. Nomer sambungan yang tidak memenuhi pun mempunyai lokasi yang serupa, hal ini dapat disebabkan durasi waktu yang menggunakan kurva S-N X lebih lama yaitu 41 tahun (1973 - 2014) dibandingkan kurva S-N WJ yaitu 8 tahun (2014 - 2022). Jika dibandingkan antara skenario 1 dan skenario 3, kurva S-N WJ lebih banyak yang tidak memenuhi dengan nilai $37 \%$. Terdapat 1 sambungan yang memiliki perbedaan hasilnya yaitu pada nomer sambungan 5014. Gambar 8 memperlihatkan lokasi nomer sambungan 5014.

Gambar 8 menunjukkan lokasi sambungan 5014 yang berada di elevasi $+4,51 \mathrm{~m}$ di atas permukaan laut, yang mana masuk pada zona basah-kering. Pada lokasi tersebut digunakan kurva S-N WJT Air (gambar 5), sehingga dapat menghasilkan nilai kerusakan yang lebih besar dibandingkan dengan Kurva S-N X. Hal tersebut dapat terjadi pada rentang tegangan sekitar 53 MPa sampai $74 \mathrm{MPa}$. Sehingga nilai umur kelelahan sambungan akan lebih kecil pada kurva S-N WJT. Perbandingan kurva S-N pada beberapa nomer sambungan dapat dilihat pada gambar 9 . 


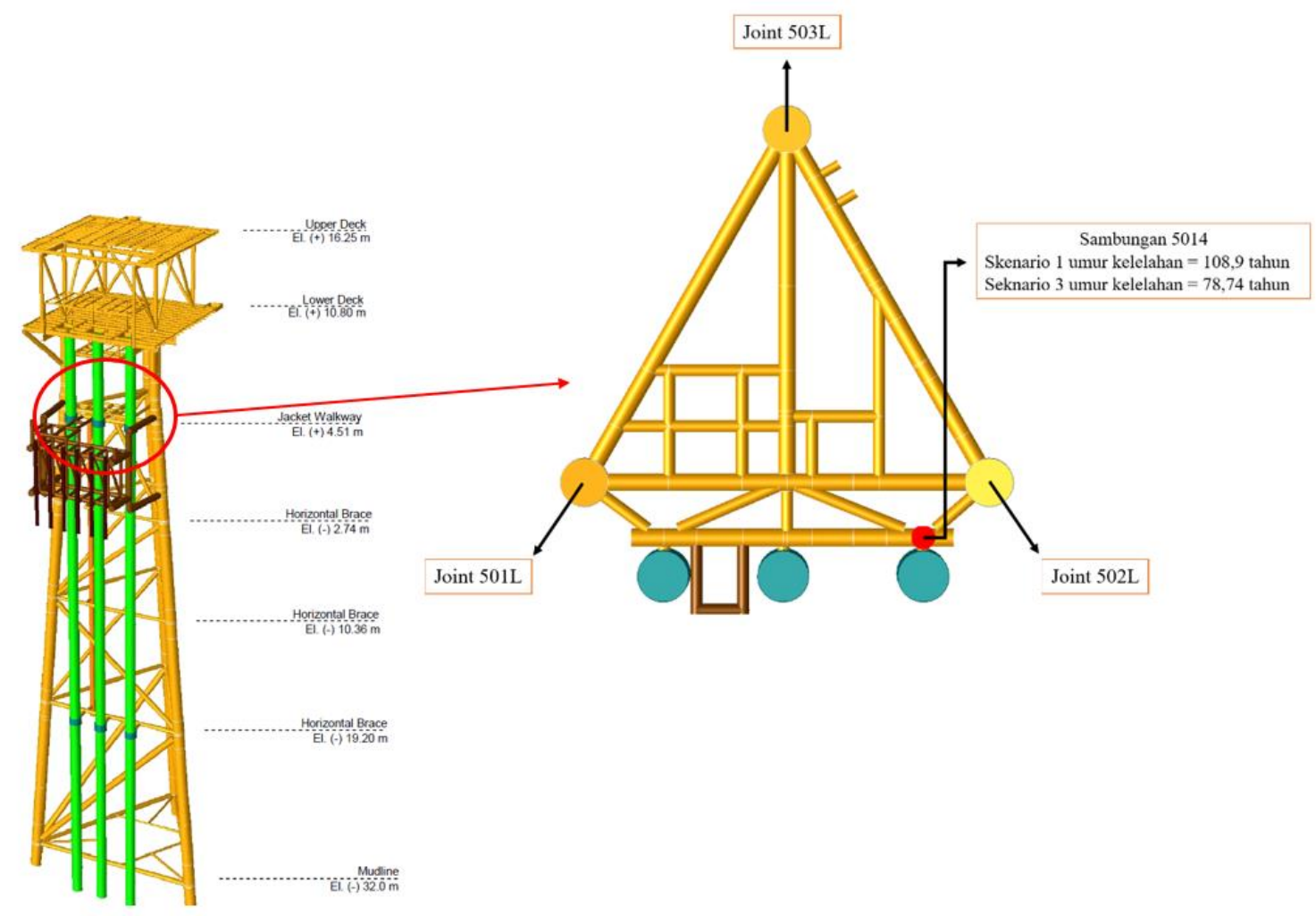

Gambar 8. Sambungan nomer 5014

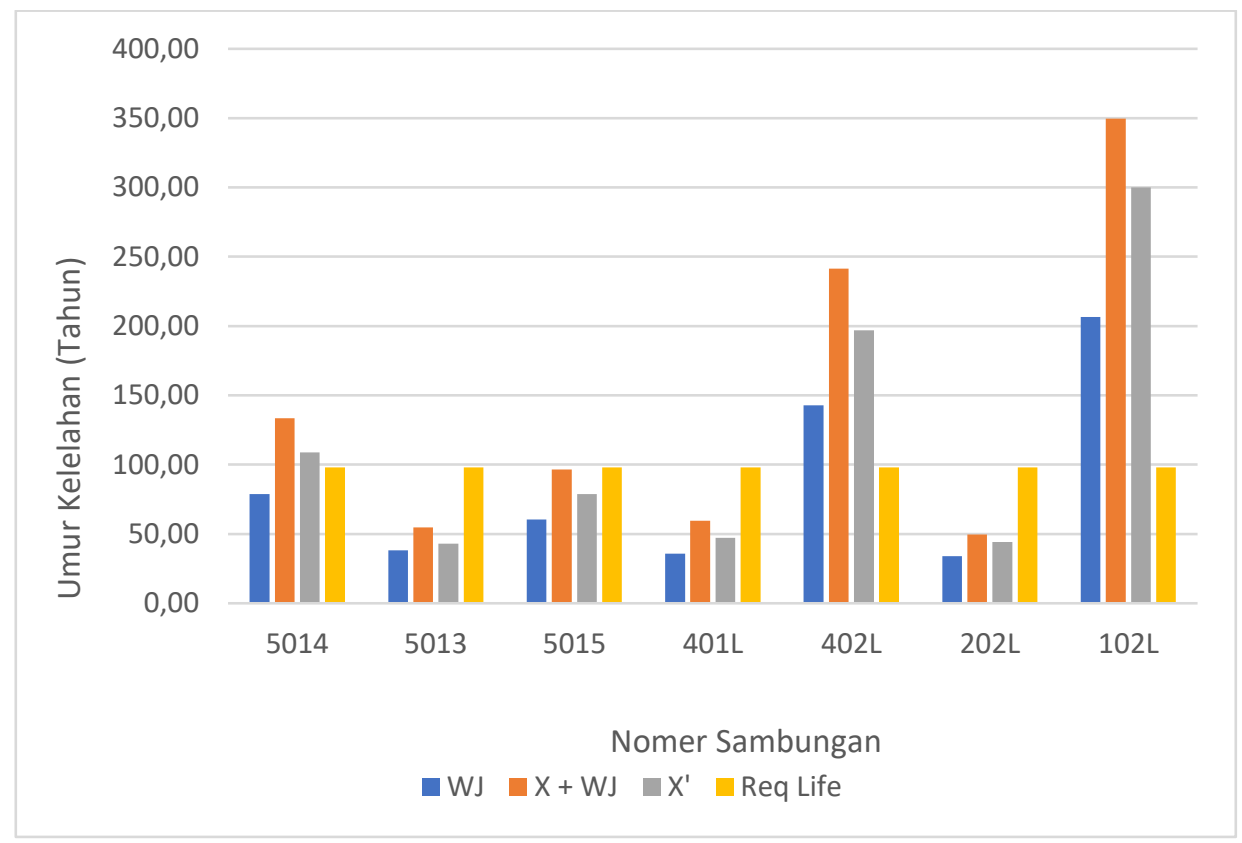

Gambar 9. Perbandingan hasil umur kelelahan

Pada gambar 9 dapat dilhat bahwa kecenderungan grafik memiliki pola yang sama pada setiap nomer sambungannya. Kombinasi kurva S-N WJT dan kurva S-N X menghasilkan umur kelelahan paling besar dibandingkan dengan penggunaan kurva S-N tersendiri. Sedangkan kurva S-N WJT menghasilkan umur kelelahan paling kecil dibandingkan dengan kurva S-N $\mathrm{X}$ dan kombinasi. Perbedaan hasil umur kelelahan secara persentase adalah $11-31 \%$ antara kurva S-N 
WJT terhadap kurva S-N X. Nilai persentase perbedaan tersebut bergantung pada lokasi dan elevasi sambungan.

\section{KESIMPULAN}

Struktur anjungan lepas pantai lama yang dibangun sejak tahun 1973 dan masih dinilai layak untuk beroperasi sampai saat ini, perlu dilakukan kajian terhadap umur kelelahan struktur. Standar API pada tahun 2014 memiliki kurva S-N yang baru dinamakan kurva S-N WJT, sedangkan yang sebelum itu terdapat kurva S-N X. Struktur anjungan lepas pantai lama memerlukan penggunaan 2 kurva S-N sebagai penentuan umur kelelahan struktur. Dalam studi ini dikaji penentuan kurva S-N apabila menggunakan kurva S-N X, Kombinasi kurva S-N X dan WJT, dan kurva S-N WJT.

Berdasarkan hasil analisis kelelahan kurva S-N WJT menghasilkan umur kelelahan yang kecil dibandingkan dengan kurva S-N X. Perbedaan umur kelelahan sambungan bergantung pada lokasi dan kedalaman. Perbedaan pada elevasi (+) 4,51 m bernilai $11 \%$ sampai $68 \%$, perbedaan pada elevasi (-) $2,74 \mathrm{~m}$ bernilai $24 \%$ sampai $44 \%$, perbedaan pada elevasi (-) $10,36 \mathrm{~m}$ bernilai $50 \%$ sampai $63 \%$, perbedaan pada elevasi (-) $19,2 \mathrm{~m}$ bernilai $23 \%$ sampai $51 \%$, dan perbedaan pada elevasi (-) 30,5 m bernilai 31\% sampai $79 \%$. Rentang perbedaan hasil tersebut yang cukup besar, dikarenakan terdapatnya perbedaan pada kemiringan kurva. Kurva S-N WJT sudah mempertimbangkan pengaruh korosi pada zona basah-kering dan bawah air, faktor ini yang dapat menjadikan hasil umur kelelahan lebih kecil daripada yang dihasilkan dari kurva S-N X.

\section{DAFTAR RUJUKAN}

[1] E. d. G. A. Arianti, "Teknologi Decommissioning Anjungan Lepas Pantai Terpancang PascaOperasi," Jurnal Inovtek Polbeng, Vol. 9, No.2, November, p. 8, 2019.

[2] A. Riyanto, "The Challenges of Oil and Gas Platform Decommissioning in Indonesia," dalam The 3rd Indo Decomm in Oil and Gas Conference, Jakarta, 2016.

[3] A. R. P. 2A-WSD, Planning, Designing, and Constructing Fixed Offshore Platforms-Working Stress Desing 22nd Edition, Washington: American Petroleum Institute, 2014.

[4] V. Sundar, Ocean Wave Mechanics-Application in Marine Structure, India: John Wiley \& Sons Ltd, 2016.

[5] Paulo et al, "Fatigue Assessments of a Jacket-Type Offshore Structure Baseon Static and Dynamic Analyses," ASCE, vol. 26, no. 1, 2020.

[6] Moura A, Tesis-Fatigue Analysis of a Jacket-Type Offshore Platform Based On Local Approaches, Universitas Porto, 2018.

[7] DNVGL, Fatigue Design of Offshore Structure, Norway: DNVGL, 2016.

[8] R. T. d. J. R, "Deterministic and Spectral Fatigue Analysis of Tubular Joints of a Jacket Platform," International Journal of Scientific \& Engineering Research, vol. 8, no. 11, p. 149, 2017.

[9] Khalifa et al, "Fatigue Assessment Analysis of Offshore Structures with Application to an Existing Platfform in Suez Gulf, Egypt," World Applied Sciences Journal, vol. 30, no. 8, pp. 1000-1019, 2014.

[10] A. R. P. 2A-WSD, Recommended Practice for Planning, Designing and Constructing Fixed Offshore Platforms-Working Stress Desing, Washington: American Petroleum Institute, 2002.

[11] AWS D1.1, Structural Welding Code-Steel, Miami: American National Standards Institute, 2000. 